Article

\title{
Evaluation of Daily Behaviors Related to Health Risks of the Ger Residents in Ulaanbaatar, Mongolia
}

\author{
Enkhchimeg Battsengel ${ }^{1,2, *}$, Takehiko Murayama ${ }^{1}\left(\right.$, Shigeo Nishikizawa ${ }^{1}$ and Sonomdagva Chonokhuu ${ }^{2}(\mathbb{D}$ \\ 1 Department of Transdisciplinary Science and Engineering, Tokyo Institute of Technology, School of \\ Environment and Society, Yokohama 226-8502, Japan; murayama.t.ac@m.titech.ac.jp (T.M.); \\ nishikizawa.s.ab@m.titech.ac.jp (S.N.) \\ 2 Department of Environment and Forest Engineering, School of Engineering and Applied Sciences, National \\ University of Mongolia, Ulaanbaatar 210646, Mongolia; ch_sonomdagva@num.edu.mn \\ * Correspondence: battsengel.e.aa@m.titech.ac.jp
}

Citation: Battsengel, E.;

Murayama, T.; Nishikizawa, S.; Chonokhuu, S. Evaluation of Daily Behaviors Related to Health Risks of the Ger Residents in Ulaanbaatar, Mongolia. Sustainability 2021, 13, 4817 https://doi.org/10.3390/su13094817

Academic Editors: Valeria Bellisario and Giulia Squillacioti

Received: 9 March 2021

Accepted: 20 April 2021

Published: 25 April 2021

Publisher's Note: MDPI stays neutral with regard to jurisdictional claims in published maps and institutional affiliations.

Copyright: (c) 2021 by the authors. Licensee MDPI, Basel, Switzerland. This article is an open access article distributed under the terms and conditions of the Creative Commons Attribution (CC BY) license (https:// creativecommons.org/licenses/by/ $4.0 /)$.
Abstract: The capital city in Mongolia comprises two types of dwellings: apartments and Gers. The Ger is a traditional Mongolian house. Residents of Ger districts in Ulaanbaatar use coal as a source of fuel for daily activities such as heating and cooking in winter due to lack of central heating systems. After coal burning, the ash deposited at the bottom of the oven converts into a powder containing heavy metals that are toxic to human health. Through questionnaires at sites where concentrations of heavy elements were identified in our previous study, we examined the heavy metal exposure pathways of coal ash, which has potentially adverse effects on the health and quality of life of Ger district residents. Survey results indicate that residents have to store the coal ash in packing bags and metal garbage cans near their household fences for at least two weeks because of poor waste management. Owing to the weak seals of the packaging material and open metal cans that contain the coal ash, it is easily transported into surrounding areas by the wind. Adults come into contact with contaminated soil when they are cleaning areas outside and inside the fences, and children are exposed when they play outside the fences. Such activities enhance the dermal exposure as well as inhalation and ingestion pathways of the contaminants for adults and children.

Keywords: exposure pathways; ingestion; inhalation; dermal; coal usage; Ger residents; questionnaire survey; principle component analyses

\section{Introduction}

Currently, approximately $45 \%$ of the total population (3.1 million people) of Mongolia resides in the capital city, Ulaanbaatar. According to a report by the National Statistics Office of Mongolia in 2018, 60\% of the residents of Ulaanbaatar live in Ger districts [1]. Owing to the lack of heating systems in the Ger districts, the residents use coal for their daily activities such as heating and cooking in the wintertime [2,3]. Numerous public health problems are caused by coal usage. In particular, coal ash has detrimental effects on air pollution and the health of people living in both Ger districts and apartments in Ulaanbaatar [4]. Although the studies concluded that there was no significant difference in health-related quality of life between both settlements during the warm season, healthrelated quality of life was worse for Ger residents in winter than for apartment residents owing to solid fuel combustion.

In addition, So et al. analyzed the lifestyle and living environment factors influencing the health of residents in Ger districts [5]. They observed that in self-reported surveys, residents cited symptoms such as eye irritation, heart-related disorders, nose and throat irritation, breathing difficulties or asthma, depression, and skin problems; illustrating the impact indoor air pollution had on the health of residents. Previous studies focused on the relationship between air pollution and public health. Likewise, soil contamination by coal ash could also have adverse effects on public health in the Ger areas. 
Coal ash contains the heavy metals arsenic, lead, mercury, cadmium, chromium, selenium, aluminum, antimony, barium, beryllium, boron, chlorine, cobalt, manganese, molybdenum, nickel, thallium, vanadium, and zinc. Such heavy metals can cause cancer and have adverse impacts on the nervous system, including cognitive deficits, developmental delays, and behavioral problems if they are eaten, drunk, or inhaled [6-8]. They can also cause heart damage, lung disease, respiratory distress, kidney disease, reproductive problems, gastrointestinal illness, birth defects, and impaired bone growth in children that live near coal ash dumpsites $[9,10]$. Furthermore, such heavy metals can be easily transported through the air, and exposed humans can easily be affected through ingestion, inhalation, and dermal contact [11,12]. Consequently, the concentrations of heavy metals in soil in the Ger areas have been measured by several researchers $[13,14]$ including our previous work [15].

Numerous studies have investigated the demographic aspects of the environmental pollution in Ger districts in Ulaanbaatar [3,16-23]. Most of them explored the effects of air pollution on the health and quality of life of Ger residents. For instance, Y. Ishihara et al., studied the effects of particulate matter pollution on respiratory health, and reported the exacerbation of respiratory symptoms and worsening of health status in individuals aged more than 40 years in Ger districts in winter [22].

In 2016, Mongolia reported 38,699 cases of respiratory infections, which is the highest number recorded over the last five years [24]. Approximately 120-130 children and 1250 adults died of pneumonia last year; this is an increase of 8715 cases compared to the number in 2015. However, there is no assessed exposure to contaminated soil, especially soil polluted by coal ash near Ger residents and the correlation of the exposure to their daily lifestyles.

In our previous work, potential human health studies were performed based on the concentration of heavy metals in the samples collected from 42 sites in the Ger area of Ulaanbaatar city, Mongolia. In total, 28 heavy metals were identified using the ICP-OES and ICP-MS methods [15]. The carcinogenic risk was estimated to exceed the permissible limit for both adults and children at all of the sample sites. The total estimated noncarcinogenic risk exceeded the permissible limit or exceeded 1 at all of the sample sites, especially for children. Therefore, it is necessary to identify their daily behaviors in relation to contaminated soil.

The present study focuses on exposure pathways based on the daily activities of Ger residents, using a questionnaire survey administered in face-to-face interviews with Ger residents who live near areas where soil samples were collected in our previous study [15]. A questionnaire survey was used because it is simple and facilitates the identification of exposure pathways and their potential effects. The aim of the present study was to explore the role of exposure pathways, including frequency and duration of exposure in the course of residents' daily activities.

Figure 1 is an illustration of a household living environment in the Ger, which is surrounded by fences. Ger residents can be exposed to coal ash pollution via dermal and inhalation pathways during the following daily activities:

1. Removal and cleaning of coal ash from ovens

2. Packing and disposal of coal ash inside and outside the fence 


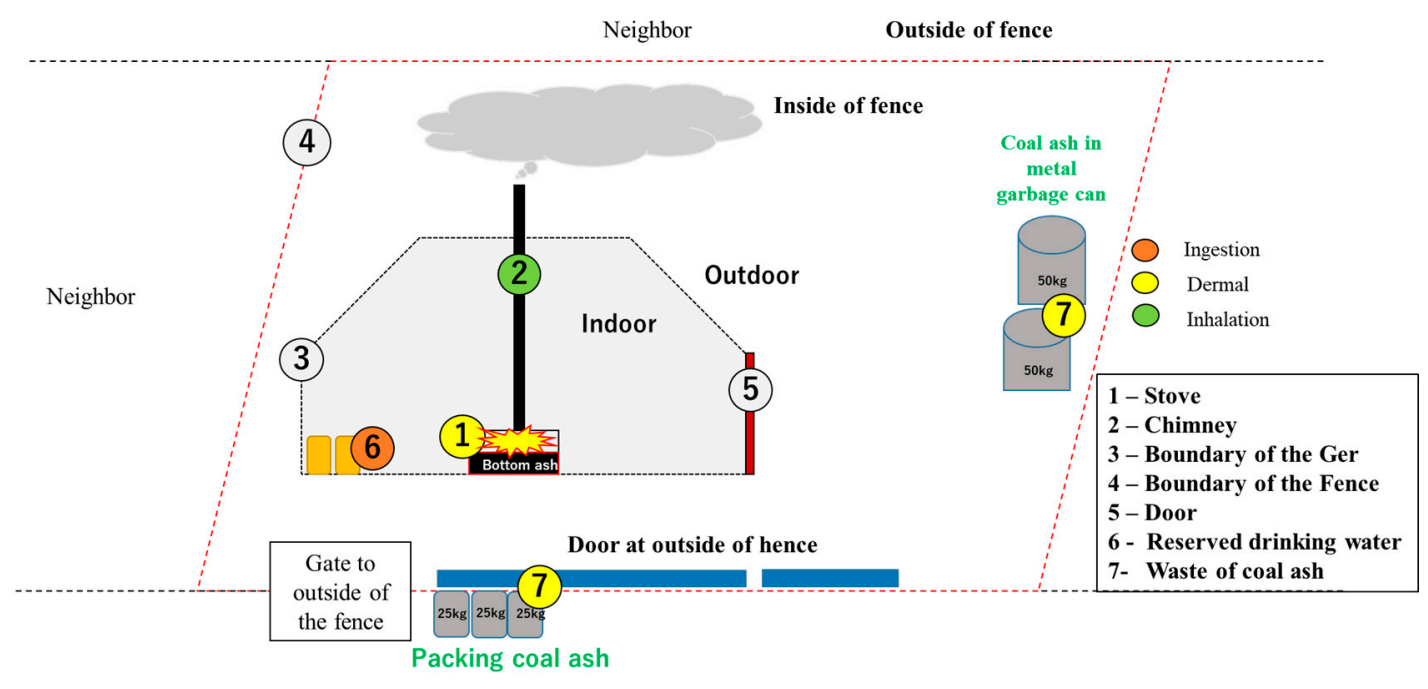

Figure 1. The block of a Ger house.

Moreover, Figure 2 illustrates how residents dispose of their waste outside the fence.

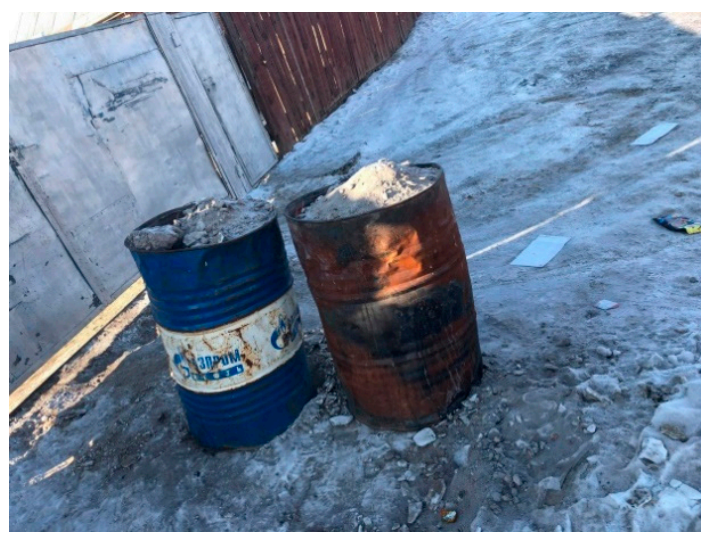

(a)

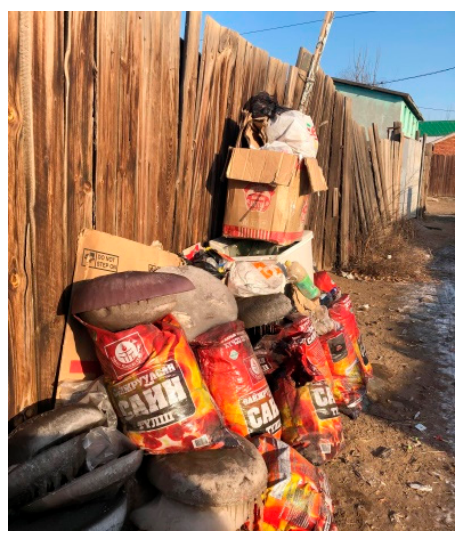

(b)

Figure 2. Photo of resident's coal ash disposal both in and outside of the fence (a) Coal ash in cans, (b) Mixed wastes.

\section{Methodology}

The present study employed a social survey approved by the Tokyo Institute of Technology to collect information and assess the heavy metal exposure of Ger area residents in Ulaanbaatar, Mongolia. This study recorded exposure pathways by using a questionnaire survey to collect information on the daily activities of Ger residents who live near the areas contaminated by heavy metals based on soil samples gathered in the our previous study, as mentioned in the introduction [15].

In the survey, 126 representative households (three households in each of the 42 soil sampling sites) were interviewed. The participants' answers were marked on a questionnaire sheet in an Excel file.

\subsection{Study Area}

The study area covered five districts in Ulaanbaatar city: Songinokhairkhan, Chingeltei, Bayanzurkh, Sukhbaatar, and Nalaikh. Triangles in Figure 3 indicate the questionnaire survey sites. The resident survey was conducted between November 2019 and January 2020. 


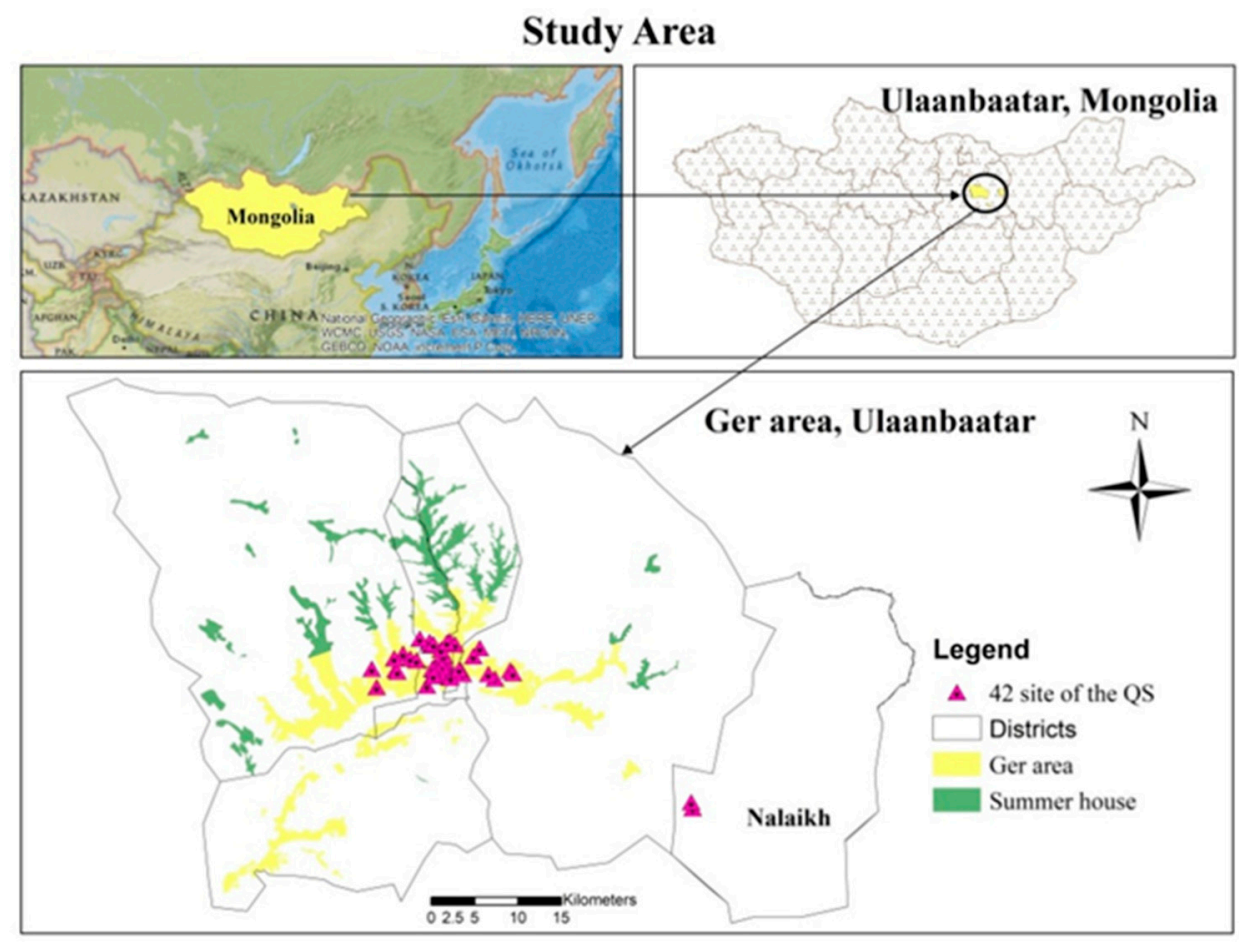

Figure 3. Questionnaire survey's sites (3 representative households from 42 points of soil samples).

\subsection{Structure of Questionnaire Survey}

In this subsection, we elaborate on the structure of the questionnaire, which is illustrated in Figure 4. The questionnaire survey consists of 36 questions divided into five major sections. The first section of the questionnaire focuses on personal information such as the age, education, and occupation of the respondent. The subsequent three sections of the questionnaire survey focus on the daily activities and health status of the residents, as well as potential exposure pathways. The final section is focused on social aspects such as willingness to improve lifestyle and modify or change their living area.

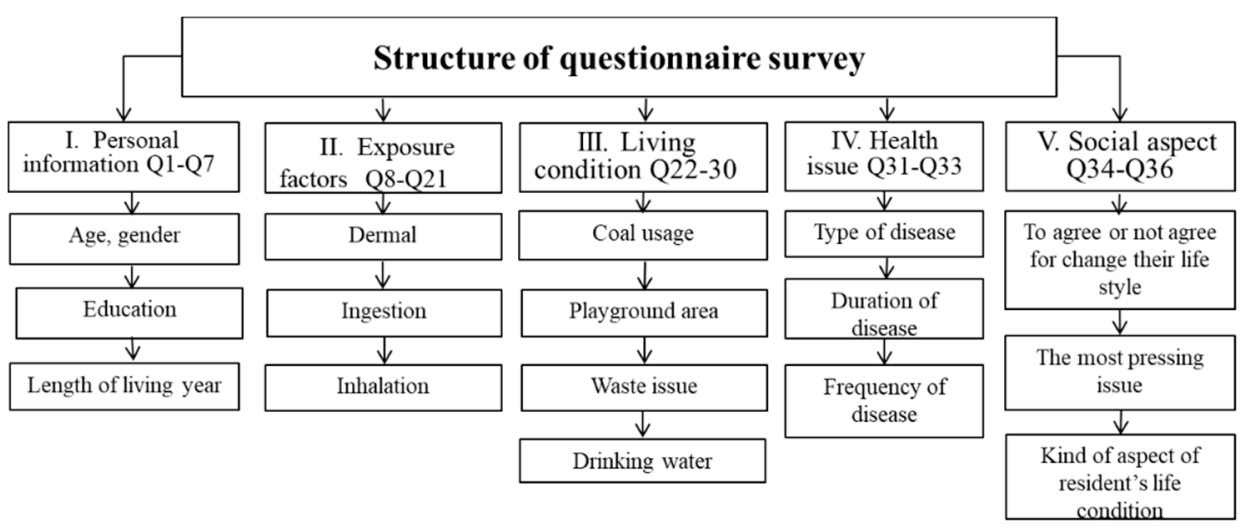

Figure 4. Structure of the questionnaire survey.

\subsection{Data Analyses}

Data analyses were performed using SPSS v15.4 (SPSS Inc., Chicago, IL, US). Descriptive and multivariate analysis results were used to describe data. Principle Component Analysis (PCA) and factor analysis methods were used to reduce large sets of variables into smaller sets named principal components, which account for most of the variance in the original data.

Survey data generated 5 main sections in the questionnaire survey sheet, as mentioned earlier. The correlation between each family member (Section 1), and daily behavior and 
social aspects (other sections) was analyzed through PCA. The PCA used Varimax rotation and Kaiser normalization. After grouping in PCA, each factor identified the relationship between pairs of values by scattering using Excel to determine the correlation.

\section{Results and Discussion}

In this section, the main findings of the questionnaire survey are reported and discussed according to the questionnaire framework.

\subsection{Personal Information}

The results of the descriptive analysis are listed in Table 1 . The total number of participants in the survey was 571 . The number of men and women that participated in the survey was $267(47 \%)$ and $304(53 \%)$, respectively. Figure 5 describes the distribution of all the participants in 17 age groups. Most of the participants were aged between 0 and 16, which was $64 \%$ of the total, while groups aged 16 and over made up 36\%. All participant information was collected from housewives and other householders during the questionnaire survey.

Table 1. Descriptive statistics of survey participants.

\begin{tabular}{ccccccc}
\hline & N & Minimum & Maximum & Mean & Std. Deviation \\
\hline 1. Family members & 571 & 1 & 9 & 2.98 & 1.61 \\
\hline 2. Age & 571 & 0.4 & 83 & 27.1 & 18.22 \\
\hline 3. Education * & 571 & 0 & 3 & 1.61 & 0.90 \\
\hline 4. Length of living location (year) & 571 & 1 & 50 & 11.81 & 8.36 \\
\hline Valid N (list wise) & 571 & & & &
\end{tabular}

* Age of nursery-0; Primary-1; Secondary-2; Higher-3.

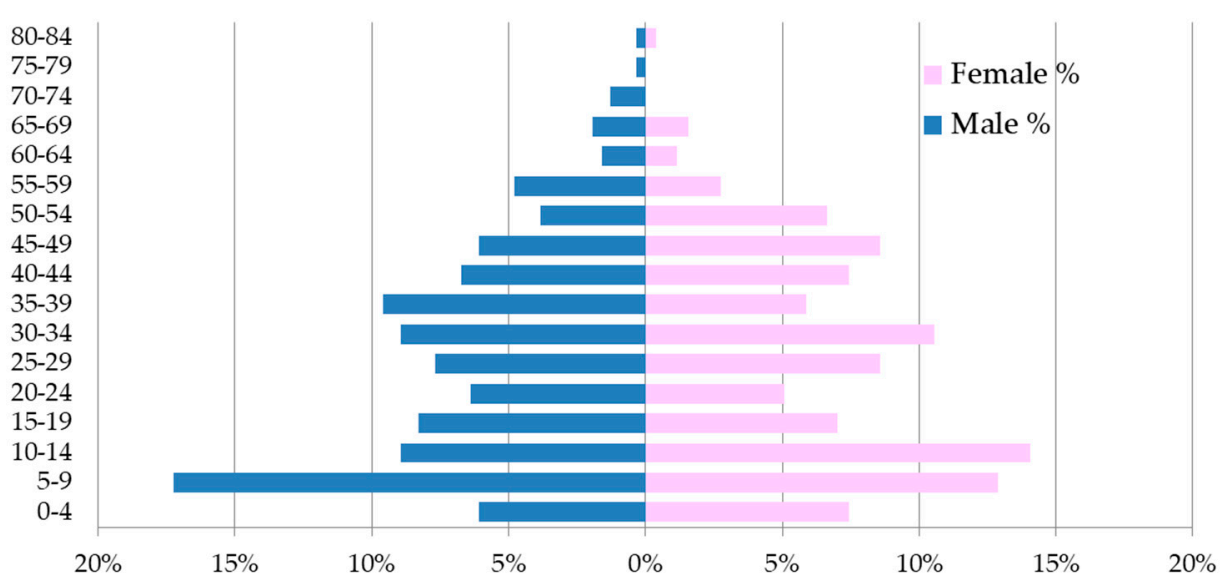

Figure 5. Age groups in the questionnaire survey.

In total, $61 \%$ of respondents are labor force age, with $20 \%$ employed and $41 \%$ unemployed. The remaining $39 \%$ of participants were children and retirees. Figure 6 describes the occupation and income of all participants in the questionnaire survey. The average salary of about $76 \%$ of the particiapnts was between $¥ 450.000$ and $¥ 850.000$ (\$157-\$297). This is lower than the Mongolian average salary, which is around $\$ 682$. The other $24 \%$ made closer to the average salary of Mongolia. This means the majority of residents make a lower salary than the Mongolian average and most of them are not working while living in poor quality conditions. 


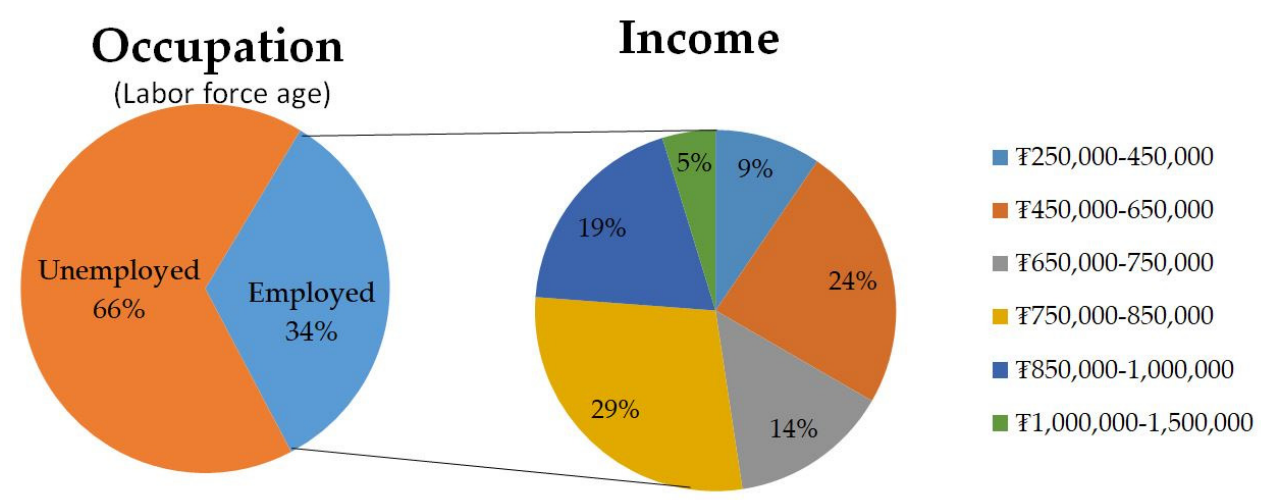

Figure 6. Occupation and income for all participants.

Figure 7 describes the education level according to age group. The education level was divided into four categories: pre-kindergarten $(n=40)$, kindergarten $(n=87)$, primary $(n=107)$, secondary $(n=225)$, and higher $(n=111)$.

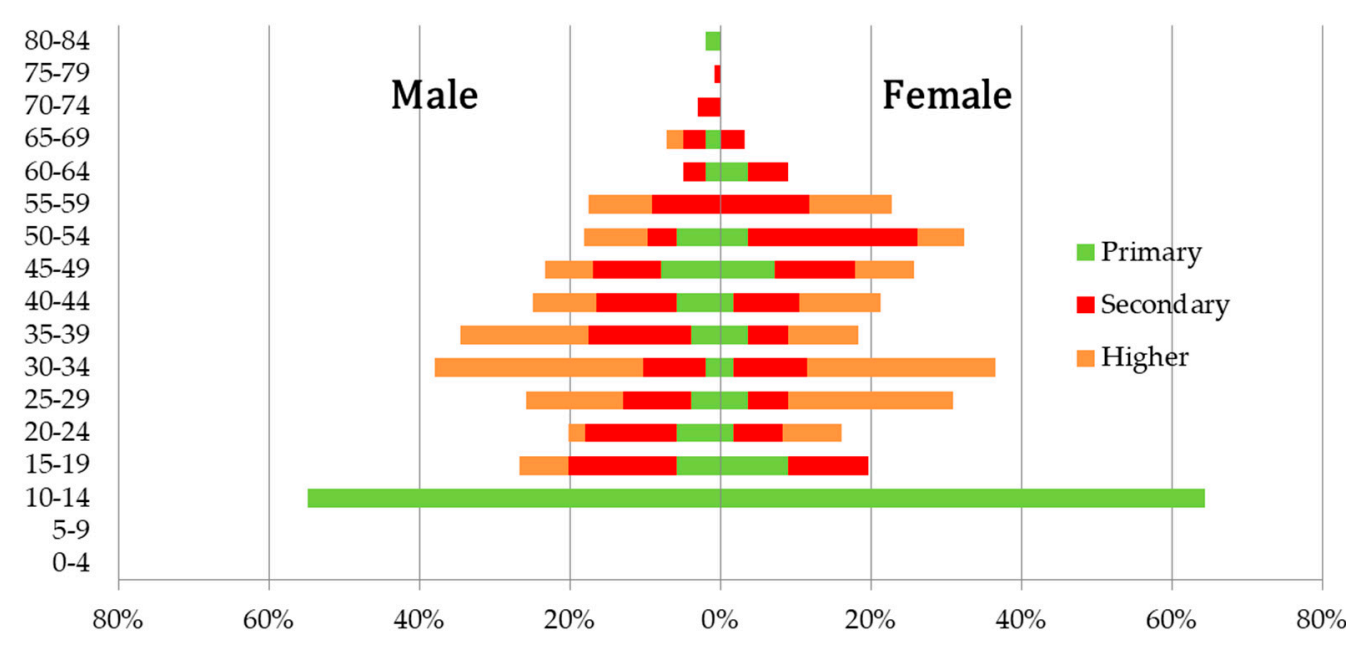

Figure 7. Education level by age groups.

Approximately $46 \%$ of participants reported that they were settled in the area for $\leq 10$ years, while the remaining $54 \%$ resided in the area for more than 10 years. The average size of land plots per Ger household is $700 \mathrm{~m}^{2}$, which is entitled to by law for individual households. The majority of land plots in Ger districts range between $470 \mathrm{~m}^{2}$ to $589 \mathrm{~m}^{2}$ per household. Private ownership of land and houses is generally high at around $99 \%$.

\subsection{Exposure Factors}

According to a health risk assessment that was performed in our previous study, the dermal exposure pathway was associated with the highest non-carcinogenic and carcinogenic risks following exposure to contaminated soil in Ger residents. Such exposure can occur when residents come into contact with contaminated media such as soil or coal ash. Questions 13-21, which focused on the daily activities of respondents, explored potential dermal exposure. According to the survey results, Ger residents (specifically adults) often come into contact with soil and coal ash when they are cleaning areas in and outside the fence. Figure 8 shows the daily behaviors of adults. Around half (51\%) of the participants reported that they spent about 11-30 min cleaning areas inside their fences. Another $49 \%$ reported that they spent more than $30 \mathrm{~min}$ and up to $2 \mathrm{~h}$ cleaning areas outside their fences. In addition, the frequency of cleaning is a key parameter influencing dermal exposure, and $53 \%$ of participants reported that they cleaned their fences once a week. Nevertheless, $88 \%$ of participants reported using safety items, such as masks, hats, and gloves, while the remaining $12 \%$ reported rarely using safety gear or not at all. 


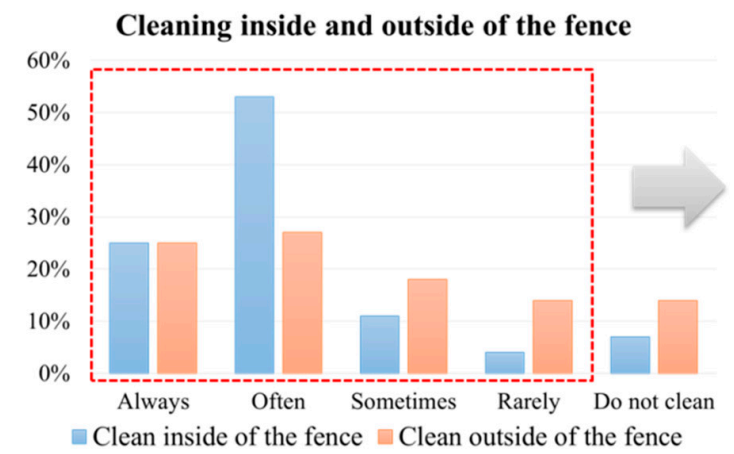

Frequency of cleaning perweek

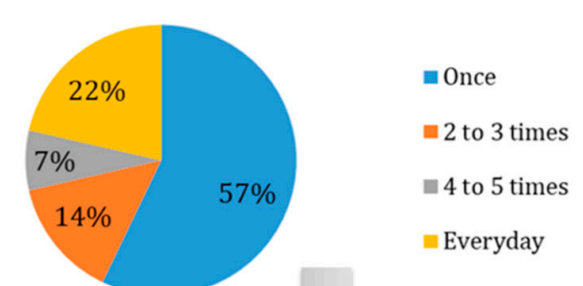

Exposure of body part from soil
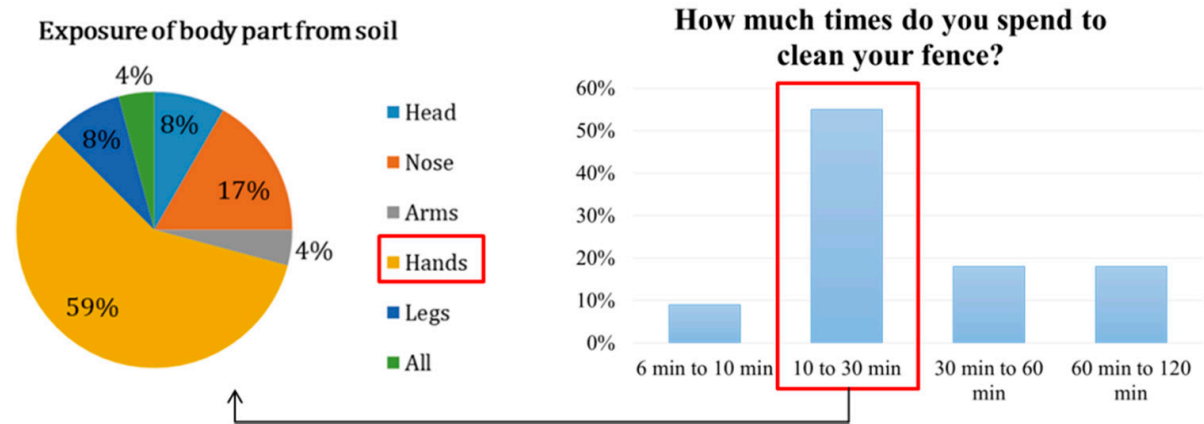

Figure 8. Daily behaviors of adults.

In the case of children, 118 children participated in the present study, and they did not have designated play areas. The child participants reported playing inside and outside their fences, as shown in Figure 9. Playing time inside and outside the fence was $30 \mathrm{~min}$ at minimum and $180 \mathrm{~min}$ at maximum.

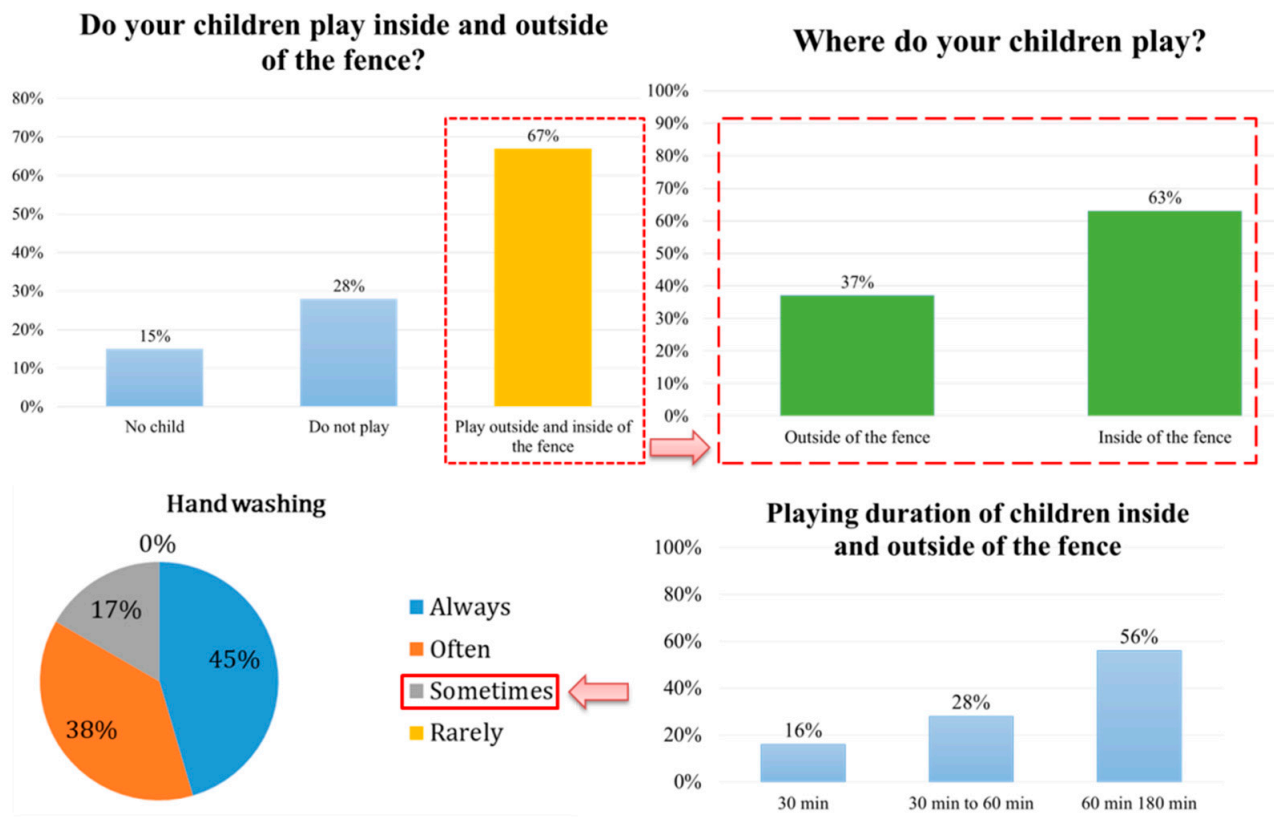

Figure 9. Daily behaviors of children.

In addition, with regard to the ingestion pathway, $45 \%$ of participants reported that they always washed their hands before eating and preparing food, while $38 \%$ and $17 \%$ reported washing their hands often and sometimes, respectively.

We considered smoke as one of the main sources of heavy metal transfer from hand to mouth in Ger residents. This study is focused on explicating this aspect of the exposure pathways in relation to contaminated soil, and not about the toxicity of smoke to human 
health. Two questions related to smoking were asked in the questionnaire. Eleven percent of the total respondents reported that they smoked a maximum of 20 cigarettes per day. Each instance of smoking is a case of ingestion of contaminant from hand to mouth. This implies that their habit of smoking after contact with contaminated soil is one of the main pathways of heavy metal ingestion.

Inhalation exposure can occur when adults and children pass through or play in contaminated soil. In addition, inhalation exposure can occur when Ger residents are cleaning their stoves and disposing of coal ash without using appropriate masks, since it is easily transported by air. In the survey, $88 \%$ of participants reported passing near the soil sampling points two to four times per day. If they passed a high-risk area for $1.5 \mathrm{~min}$ per day, the duration of spent time at high risk could be $9.1 \mathrm{~h}$ per year. Figure 10 shows the results of questions length of living year and frequency of pass sampling points per day in questionnaire surveys.

\section{Length of livingyear}

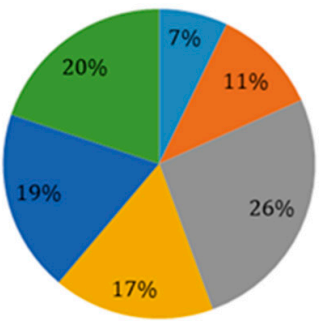

nless 1 year

$\| 1$ to 5 years

$=6$ to 10 years

$=11$ to 15 years

- 16 to 20 years

= More than 20 years

\section{Frequency of pass at sampling pointa per day}

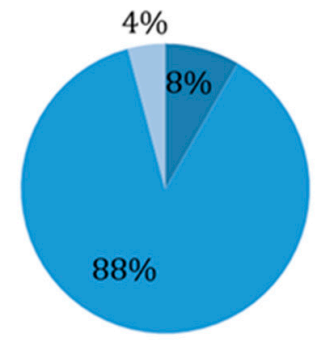

घ 1 time

m 2 times

프 4 to 5 times

Figure 10. Length of living year and frequency of pass sampling points per day.

\subsection{Living Conditions}

Based on the results of the questionnaire survey, coal ash is one of the main sources of soil pollution in the Ger area. At least $1565 \mathrm{~kg}$ of coal is generated by $126 \mathrm{Ger}$ households per day. The residents keep the coal ash in packing bags and metal garbage cans (Figure 5) outside and inside the fence for at least two weeks because of poor waste management. Owing to weak seals and open metal cans, coal ash waste could easily be transported by wind and air into surrounding areas. The respondents reported that briquette coal had reduced levels of air pollution in the capital city and increased thermal capacity; however, it increased the quantity of coal ash disposed of by more than around 3-5 $\mathrm{kg}$ per packing than in previous years. Coal is the main source of fuel for Ger residents in the wintertime. All the residents use coal from October to April. They use 21-30 kg of coal per day and generate the same amount of coal ash. Figure 11 shows coal usage and coal ash quantity.

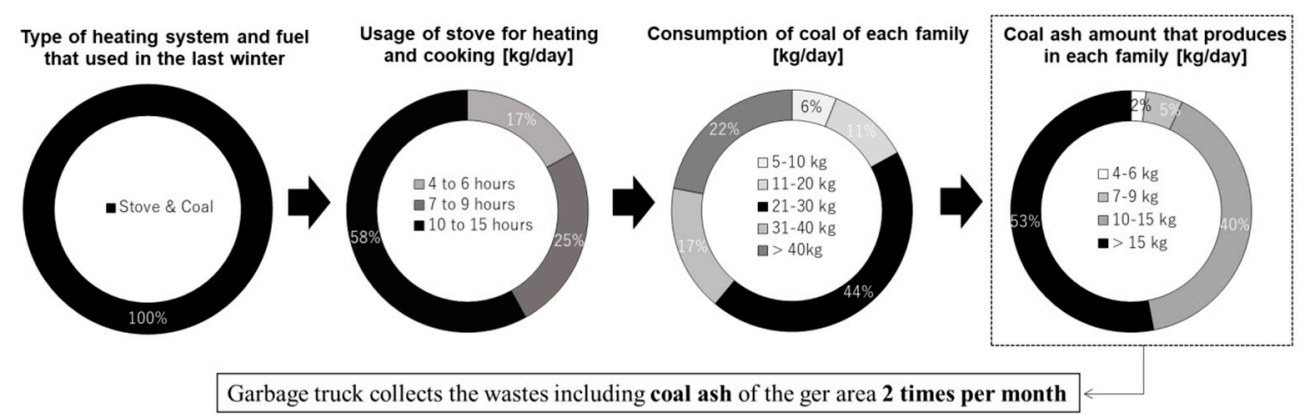

Figure 11. Coal usage and quantity of coal ash disposal.

\subsection{Health Issues}

Participants reported their health conditions according to the questions in the survey. According to the results, most of the respondents considered their health status as Good (51\%), followed by Neither good nor bad (26\%), Very good (17\%), and Bad (6\%). According 
to Figure 12, in the cold season, approximately $46 \%, 35 \%$, and $19 \%$ of residents reported various symptoms such as rheum, lung disease, and sore throat, respectively. In winter, their children had similar diseases, however, the frequency of symptoms was higher in children than in adults. All the respondents reported none of the symptoms mentioned above during the summer.
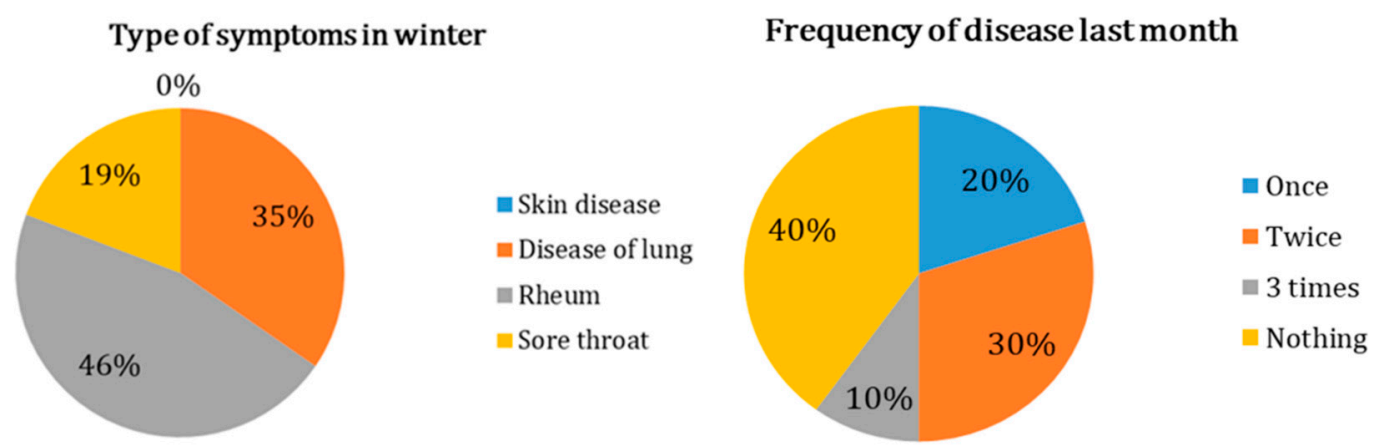

Figure 12. Health issues in winter time.

Previous studies by Byambadorj, et al. [3] and Nakao et al. [4] mentioned the same issues concerning health over the duration of winter. Moreover, So et al. reported Ger residents taking off their shoes when they came inside. As mentioned in these results, some of them tried to wash the dust off their shoes when they came into the Ger. This could also have worsened their health issues as they wore the same set of shoes both in and outside of the Ger, and most of the roads in the Ger district in Ulaanbaatar are unpaved [5].

\subsection{Social Aspects}

The last part of the questionnaire explored the social aspects of residents, with participants answering questions related to quality of life and district issues needing to be resolved. According to most of the residents, waste management was the priority, which is shown in Figure 13. According to the residents, the frequency of waste collection should be increased, considering the waste is collected only two times a month. Other issues considered by the participants to be a priority in the Ger area included kindergartens, heating systems, toilets, schools, and drinking water.

Issue that need to be solved in the ger areas

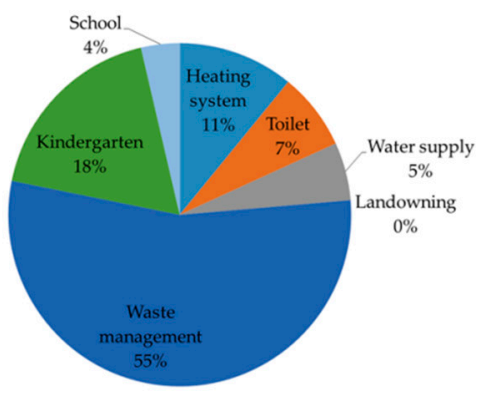

To agree to move to their living land due to improve their living condition

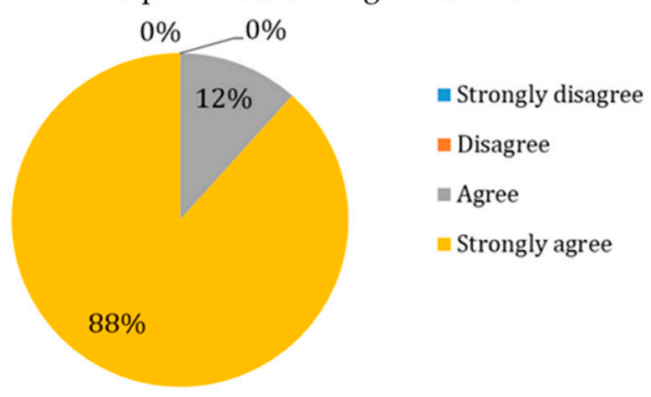

Figure 13. Required issues to be solved near future (recommended by residents).

In addition, primary school attendance is less in Ger districts than in other apartment areas. Most of the schools are located too far from the children's homes. Some of them travel to school at least $1-2 \mathrm{~km}$ by foot. Moreover, the duration of their stay is limited owing to the lack of school capacity. After 3-5 h, they must go back to their homes. This is a high-pressure issue for children. However, only about $4 \%$ of the adult participants were concerned because there are many problems in the Ger area other than lack of schooling. 
Overall, each of the respondents reported a desire to improve their quality of life and strongly agreed that they would give up their land ownership for an apartment dwelling. Figure 6 shows the most pressing issues for Ger district residents.

\subsection{Principal Component Analysis (PCA) Results}

This section reports the PCA results. Before performing PCA, Bartlett's test of sphericity and Kaiser-Meyer-Olkin (KMO) were performed to measure sample adequacy. The results of the Bartlett test of sphericity and KMO showed that the data is sufficient $(p<0.0)$ and adequate $(p>0.8)$ for PCA analysis. The total variance and rotated component matrix results are listed in Tables 2 and 3, respectively. The four factor analyses were extracted and grouped. Four components explained $72.7 \%$ of the variance.

Table 2. Total Variance. Extraction Method: Principal Component Analysis

\begin{tabular}{|c|c|c|c|c|c|c|c|c|c|}
\hline \multirow{2}{*}{ Component } & \multicolumn{3}{|c|}{ Initial Eigenvalues } & \multicolumn{3}{|c|}{ Extraction Sums of Squared Loadings } & \multicolumn{3}{|c|}{ Rotation Sums of Squared Loadings } \\
\hline & Total & $\%$ of Variance & Cumulative $\%$ & Total & $\%$ Variance & Cumulative \% & Total & $\%$ Variance & Cumulative \% \\
\hline 1 & 6.711 & 47.937 & 47.937 & 6.711 & 47.937 & 47.937 & 6.566 & 46.899 & 46.899 \\
\hline 2 & 1.326 & 9.474 & 57.411 & 1.326 & 9.474 & 57.411 & 1.306 & 9.332 & 56.231 \\
\hline 3 & 1.109 & 7.924 & 65.335 & 1.109 & 7.924 & 65.335 & 1.205 & 8.607 & 64.838 \\
\hline 4 & 1.042 & 7.443 & 72.778 & 1.042 & 7.443 & 72.778 & 1.112 & 7.940 & 72.778 \\
\hline 5 & 0.909 & 6.496 & 79.274 & & & & & & \\
\hline 6 & 0.796 & 5.683 & 84.957 & & & & & & \\
\hline 7 & 0.678 & 4.843 & 89.800 & & & & & & \\
\hline 8 & 0.454 & 3.246 & 93.046 & & & & & & \\
\hline 9 & 0.401 & 2.863 & 95.909 & & & & & & \\
\hline 10 & 0.257 & 1.838 & 97.747 & & & & & & \\
\hline 11 & 0.141 & 1.009 & 98.757 & & & & & & \\
\hline 12 & 0.105 & .751 & 99.507 & & & & & & \\
\hline 13 & 0.066 & .472 & 99.979 & & & & & & \\
\hline 14 & 0.003 & .021 & 100.000 & & & & & & \\
\hline
\end{tabular}

Table 3. Rotated Component Matrix.

\begin{tabular}{ccccc}
\hline Questionnaire & \multicolumn{3}{c}{ Component } \\
\cline { 2 - 4 } & $\mathbf{1}$ & $\mathbf{2}$ & $\mathbf{3}$ & $\mathbf{4}$ \\
\hline 34. To change their lifestyle & 0.898 & -0.185 & -0.080 & -0.019 \\
\hline $\begin{array}{c}\text { or not } \\
\text { 35. To collect to idea about changing } 4\end{array}$ & 0.895 & -0.179 & -0.078 & -0.020 \\
\hline $\begin{array}{c}\text { 22. How many kilograms do you } \\
\text { usually disposal the coal ash wastes in } \\
\text { winter time per day? }\end{array}$ & 0.882 & -0.150 & -0.076 & 0.007 \\
\hline $\begin{array}{c}\text { 17. Do you clean inside of your fence } \\
\text { around the home? }\end{array}$ & 0.868 & 0.109 & 0.351 & 0.010 \\
\hline $\begin{array}{c}\text { 19. How many minutes do you spent } \\
\text { for clean the fence? }\end{array}$ & 0.859 & -0.130 & -0.134 & 0.027 \\
\hline $\begin{array}{c}\text { 16. Do you clean outside of fence } \\
\text { around your home? }\end{array}$ & 0.856 & 0.082 & 0.350 & 0.024 \\
\hline $\begin{array}{c}\text { 20. Do you use the safety items such as } \\
\text { gloves and mask while you are } \\
\quad \text { cleaning? }\end{array}$ & 0.831 & -0.033 & 0.128 & -0.053 \\
\hline $\begin{array}{c}\text { 18. How many times do you usually } \\
\text { clean the fence per week? }\end{array}$ & 0.829 & 0.121 & 0.412 & -0.001 \\
\hline $\begin{array}{c}\text { 29. Duration of keep drink water (day) } \\
\quad\end{array}$ & 0.746 & -0.255 & -0.254 & 0.072 \\
\hline
\end{tabular}


Table 3. Cont.

\begin{tabular}{ccccc}
\hline \multirow{2}{*}{ Questionnaire } & \multicolumn{4}{c}{ Component } \\
\cline { 2 - 5 } & $\mathbf{1}$ & $\mathbf{2}$ & $\mathbf{3}$ & $\mathbf{4}$ \\
\hline $\begin{array}{c}\text { 14. How many hours do your childre } \\
\text { play the playground area? }\end{array}$ & -0.137 & 0.715 & -0.015 & 0.133 \\
\hline $\begin{array}{c}\text { 11. How many hours do your family } \\
\text { members stay at home per day? }\end{array}$ & -0.062 & 0.665 & -0.292 & -0.129 \\
\hline $\begin{array}{c}\text { 10. If you smoking, how many } \\
\text { cigarettes do you or your family smoke } \\
\text { per day? }\end{array}$ & 0.008 & -0.329 & 0.763 & -0.024 \\
\hline $\begin{array}{c}\text { 12. How many times do you and your } \\
\text { family members pass around the }\end{array}$ & 0.008 & -0.130 & -0.056 & 0.759 \\
\hline $\begin{array}{c}\text { sampling site per day? } \\
\text { 8. Do you and your family member's } \\
\text { hand washing before eating food and } \\
\text { drinks? }\end{array}$ & 0.001 & 0.153 & 0.042 & 0.700 \\
\hline$\quad$ Initial Eigen values & 6.56 & 1.31 & 1.2 & 1.110 \\
\hline
\end{tabular}

Extraction Method: Principal Component Analysis. Rotation Method: Varimax with Kaiser Normalization. Rotation converged in 7 iterations

The rotated component score contained variables with strong correlation results based on bivariate analysis. Four components that explained $72.7 \%$ of the variance were extracted and grouped using PCA. The first principal component explained $46.9 \%$ of the total variance. Results show higher scores with the highest probability of their daily activity related to coal waste during time spent drinking water and cleaning fences. Therefore, Factor 1 was labeled "daily activity". The second component explained $9.3 \%$ of the variance, and it was related to the playground area and time spent staying at home. Therefore, Factor 2 was labeled "time of staying home". The third principal component explained $8.6 \%$ of the variance. It explains that the smoking quantity scored the highest values in component 3. Therefore, Factor 3 is labeled as "frequency of smoking". The fourth principal component explained $7.9 \%$ of the variance and was associated with frequency of family members passing through the sampling sites each day and hand washing. Consequently, Factor 4 is labeled "source of exposure".

Factor analysis results based on the first two principal components accounting for most of the variance are illustrated in Figures 14-16. Figure 14 illustrates the relationship between daily activity and time spent staying at home based on employment status and education level. According to Figure 14, more educated and employed individuals are more active than the unemployed and retirees, as well as children, who also spend more time at home.

From a health and safety perspective, relatively educated and employed people use safety gear such as gloves and masks when they are cleaning their fences. Moreover, they are eager to change and improve their living conditions and lifestyles. Conversely, in Figure 15, the relationship between daily activities and time staying at home are demonstrated in terms of age and duration of residence in the Ger districts. All respondents reported cleaning their fences. However, according to Figure 15, the residents aged more than 19 years tended to spend more time on daily activities and stayed home less when compared with children; which is reasonable because children in the Ger districts stay at home except during school time. In the case of infants, they stay home with their parents or grandparents due to inadequate nursery and kindergarten facilities. According to Figure 16, educated and employed people were at greater risk of exposure to contaminated soil compared to children, the unemployed, and retirees, who all spent most of their time at home (Figure 14). The employed and the relatively educated pass through the sample sites at least two times a day as they go to work and schools, according to the results of the survey. 


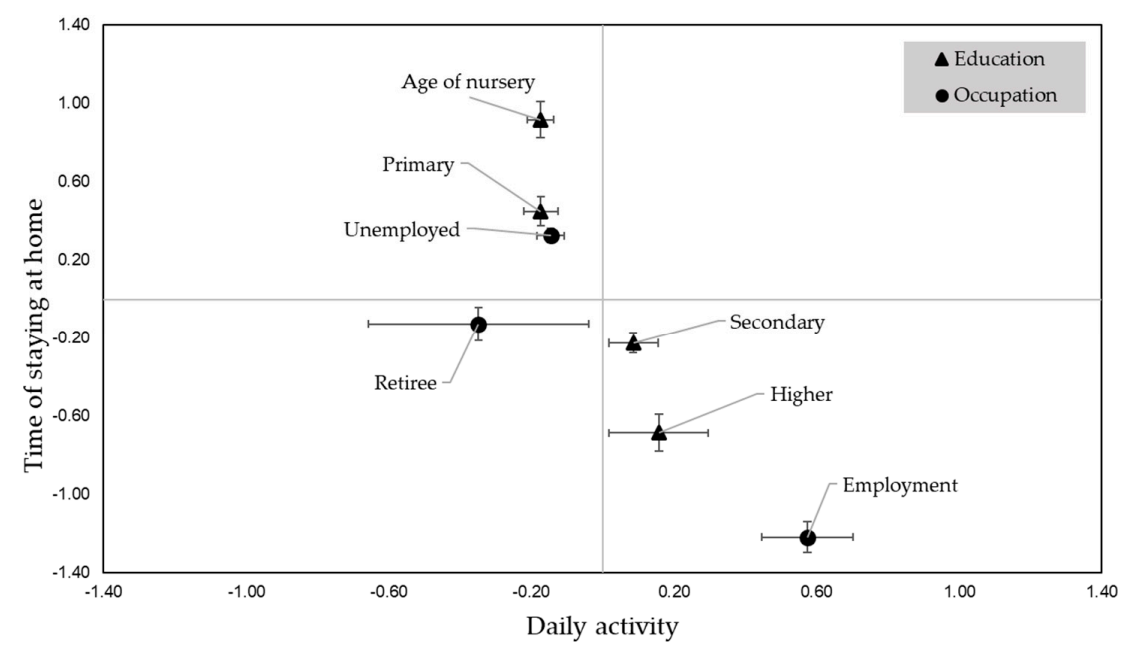

Figure 14. Relationship between daily activities and time of staying at home. Regarding to respondent's education and employment condition.

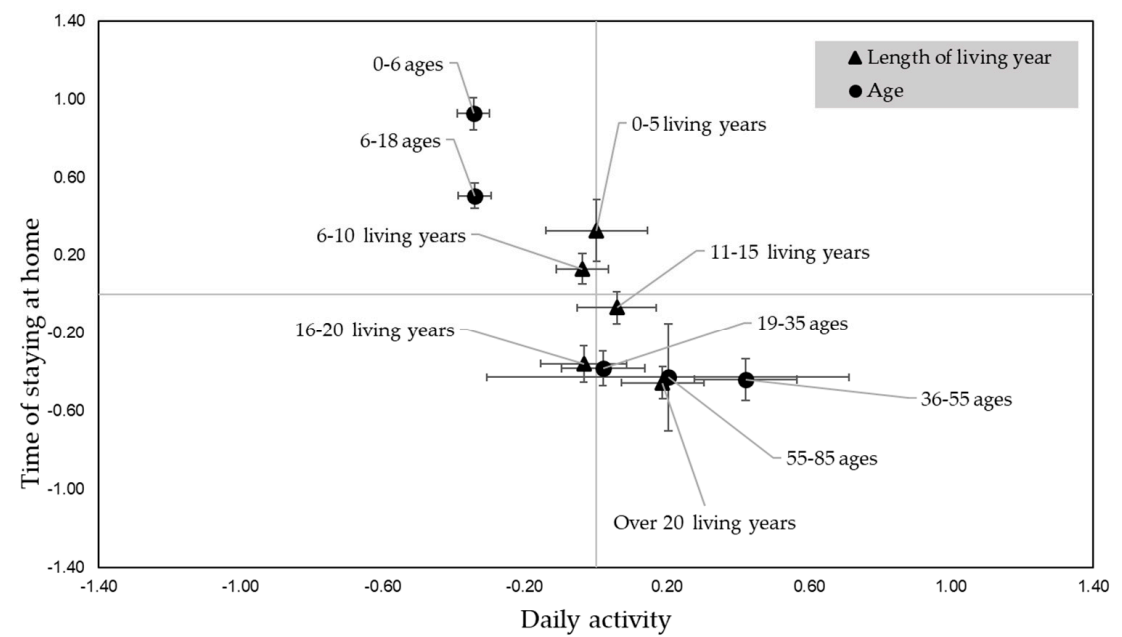

Figure 15. Relationship between daily activities and time of staying at home. Regarding to respondents age and length of living year.

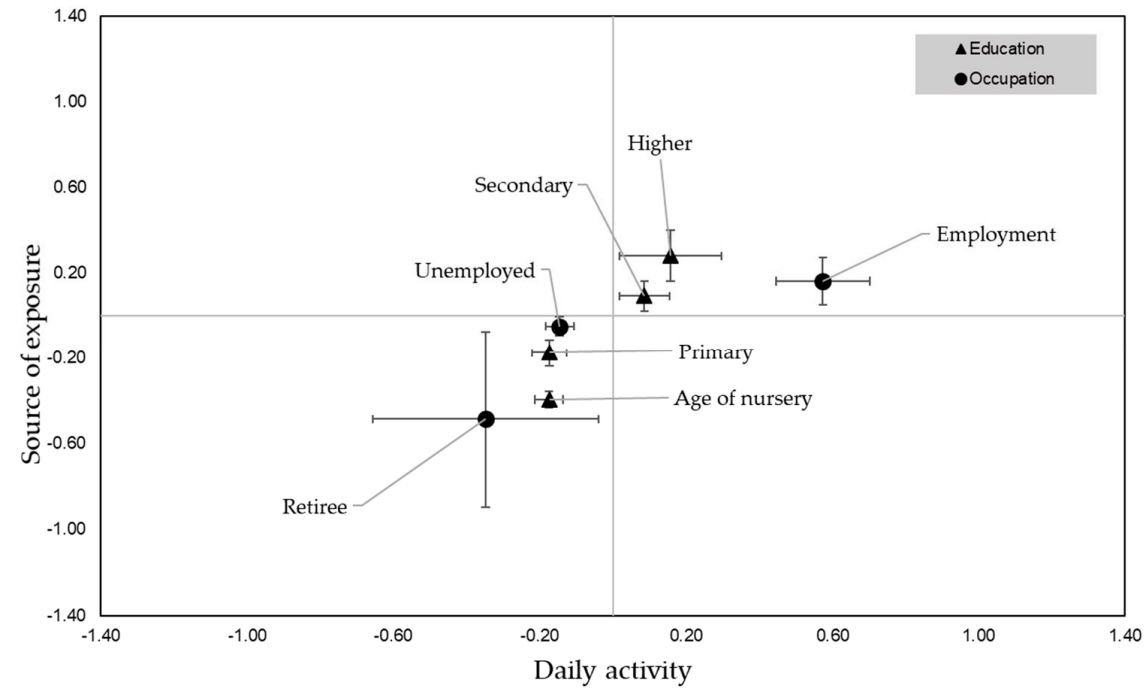

Figure 16. Relationship between daily activities and source of exposure. Regarding to respondents education and employment. 


\section{Conclusions}

In this study, we explored the potential heavy metal exposure pathways for Ger residents based on their lifestyles using face-to-face questionnaires. All respondents reported using coal as a source of heating and cooking, but only in wintertime. During the winter, each household burns approximately $25 \mathrm{~kg}$ of coal and an equivalent amount of coal ash is produced per day. All respondents answered that they dispose of the coal ash but it is left for two weeks in or outside of their fences until garbage trucks collect them. Most of the Ger residents do not dispose of the coal ash in sealed dust bins. Consequently, over the two-week period, the surrounding area becomes contaminated because coal ash is easily transported by wind, leading to the contamination of the soil in the Ger area.

Ger district residents could get exposure by coming into contact with the contaminated soil when they are cleaning areas both in and outside their fences. According to survey results, adult Ger residents' hands and noses often become dirty, indicating dermal and inhalation exposure pathways of coal ash pollution. In the case of children, dermal, inhalation, and ingestion exposure can occur when they play inside or outside the fence. Based on the disease history of respondents, rheum, lung disease, and sore throat were the major symptoms. According to factor analysis, when compared with unemployed individuals, retirees, and children, the employed and those with more education were more at risk of exposure because they are relatively more active in their fence cleaning activities, and in turn, more likely to come into contact with contaminated soil.

The capital city has expanded to 30 times larger than the original inhabited areas, especially by Ger districts. The Mongolian government has been developing strategic policies since 2013, such as Master Plans, to better manage the expansion of Ger areas. However, its improvements on urban services are slow. Ger areas have been continuing to expand until recently, and the local government's capacity to respond to these challenges is still limited [25].

As a consequence of the incomplete combustion in traditional inefficient stoves, coal combustion in Gers is the main source of air pollution not only because of particulate matter but also soil pollution. This makes Ulaanbaatar one of the most polluted cities in the world [26-28]. Environmental pollution of the capital city is mainly derived from incomplete coal combustion in Gers, and frequently exceeds 10 times the national permissible level $\left(50 \mu \mathrm{g} / \mathrm{m}^{3}\right)$ in winter [28]. Therefore, coal combustion emissions may be one of the major sources of metal pollution in Ulaanbaatar soil.

We have identified the frequency and time of three exposure pathways from contaminated soil of the Ger areas. The main findings of this present study will be the basis of our future research relating to quantitative evaluation of exposure pathways to reduce adverse effects on human health from contaminated soil. This study can be a helpful source to reduce risk and improve the social, economic and legal environment.

Author Contributions: Conceptualization, E.B. and T.M.; Methodology, E.B.; Software, E.B.; Data curation, E.B.; Writing-Original draft preparation, E.B. and T.M.; S.N.; Writing-Review and editing E.B., T.M. and S.N.; Visualization, E.B.; Supervision, T.M.; Project administration, S.C.; All authors have read and agreed to the published version of the manuscript.

Funding: This research was funded by the functional materials based on Mongolian natural minerals for environmental engineering, cementitious and flotation processes (No. J11A15) sub-project under the Mongolian-Japanese Engineering Education Development Project. This paper was also funded by the National University of Mongolia under grant agreement (P2019-3727).

Institutional Review Board Statement: The study was conducted after employed a social survey approved by the human-related research ethics of Tokyo Institute of Technology (protocol code 19372 and 2019.12.20 approved).

Informed Consent Statement: Informed consent was obtained from all subjects involved in the study.

Data Availability Statement: Not applicable. 
Acknowledgments: We are grateful to the members of the functional materials based on Mongolian natural minerals for environmental engineering, cementitious and flotation processes (No. J11A15) sub-project, staff of the Mongolian-Japanese Engineering Education Development Project, and National University of Mongolia.

Conflicts of Interest: The authors declare no conflict of interest.

\section{References}

1. National Statistics Office of Mongolia. 2018. Available online: https:/ / www.en.nso.mn/ (accessed on 5 May 2020).

2. Purev, U.-U.; Hagishima, A. A Field Survey of Traditional Nomadic Dwelling Gers Used as Urban Habitats in Ulaanbaatar, Mongolia. Evergreen 2020, 7, 155-171. [CrossRef]

3. Byambadorj, T.; Amati, M.; Ruming, K.J. Twenty-first century nomadic city: Ger districts and barriers to the implementation of the Ulaanbaatar City Master Plan. Asia Pac. Viewp. 2011, 52, 165-177. [CrossRef]

4. Nakao, M.; Yamauchi, K.; Ishihara, Y.; Omori, H.; Ichinnorov, D.; Solongo, B. Effects of air pollution and seasons on health-related quality of life of Mongolian adults living in Ulaanbaatar: Cross-sectional studies. BMC Public Health 2017, 17, 594. [CrossRef]

5. So, Y.; Lee, N.; Kim, S.; Lee, Y.; Ochir, C.; Lee, K. Characteristics of Lifestyle and Living Environment of Ger District Residents in Ulaanbaatar, Mongolia. Korean J. Public Health 2019, 55, 12-21. [CrossRef]

6. RTI Human and Ecological Risk Assessment of Coal Combustion Wastes. Available online: http://www.southeastcoalash.org/ wp-content/uploads/2012/05/epa-coal-combustion-waste-risk-assessment.pdf (accessed on 5 May 2020).

7. Diaz-Loya, E.I.; Allouche, E.N.; Eklund, S.; Joshi, A.R.; Kupwade-Patil, K. Toxicity mitigation and solidification of municipal solid waste incinerator fly ash using alkaline activated coal ash. Waste Manag. 2012, 32, 1521-1527. [CrossRef] [PubMed]

8. Jang, J.; Ahn, Y.; Souri, H.; Lee, H. A novel eco-friendly porous concrete fabricated with coal ash and geopolymeric binder: Heavy metal leaching characteristics and compressive strength. Constr. Build. Mater. 2015, 79, 173-181. [CrossRef]

9. Barry Breen; Acting Assistant Administrator; Office of Solid Waste and Emergency Response; US EPA. Testimony Delivered to Committee on Transportation and Infrastructure, Subcommittee on Water Resources and the Environment; U.S. House of Representatives: Washington, DC, USA, 2009.

10. U.S. Environmental Protection Agency (EPA). Human and Ecological Risk Assessment of Coal Combustion Wastes; (Draft); (Released as Part of a Notice of Data Availability); RTI: Durham, NC, USA, 2007.

11. Regulatory Determination on Wastes from the Combustion of Fossil Fuels (Final Rule). Fed. Regist. $2000,65,32218$.

12. Guidelines for Human Exposure Assessment Risk Assessment Forum U.S. Environmental Protection Agency, 2016. Peer Review Draft. 7 January 2016. Available online: https:/ / www.epa.gov/sites/production/files/2016-02/documents/guidelines_for_ human_exposure_assessment_peer_review_draftv2.pdf (accessed on 24 April 2021).

13. Sonomdagva, C.H.; Chultem, B.; Byambatseren, C.H.; Enkhchimeg, B.; Batsuren, D.; Batdelger, B. Contamination and Health Risk Assessment of Heavy Metals in the Soil of Major Cities in Mongolia. Int. J. Environ. Res. Public Health 2019, 16, 2552. [CrossRef]

14. Byambasuren, T.S.; Khuukhenkhuu, B.; Ochirbat, G.; Vasilyeva, I.E.; Shabanova, E.V.; Tsedenbaljir, D.; Korolkov, A.T. Background concentration of microelements in Ulaanbaatar regional natural surface soil. Proc. Mong. Acad. Sci. 2018, 15-24, 15-24. [CrossRef]

15. Battsengel, E.; Murayama, T.; Fukushi, K.; Nishikizawa, S.; Chonokhuu, S.; Ochir, A.; Tsetsgee, S.; Davaasuren, D. Ecological and Human Health Risk Assessment of Heavy Metal Pollution in the Soil of the Ger District in Ulaanbaatar, Mongolia. Int. J. Environ. Res. Public Health 2020, 17, 4668. [CrossRef] [PubMed]

16. Enebish, T.; Chau, K.; Jadamba, B.; Franklin, M. Predicting ambient PM2.5 concentrations in Ulaanbaatar, Mongolia with machine learning approaches. J. Expo. Sci. Environ. Epidemiol. 2020, 1-10. [CrossRef] [PubMed]

17. Institute of Geoecology of the Mongolian Academy of Sciences. To Determine the Negative Impact of Sources on Groundwater Quality and Resources in Ger Districts; Institute of Geoecology of the Mongolian Academy of Sciences: Ulaanbaatar, Mongolia, 2013.

18. Caldieron, J.M. Ger Districts in Ulaanbaatar, Mongolia: Housing and Living Condition Surveys. Int. J. Innov. Appl. Stud. 2013, 4, 465-476.

19. Ban, H.; Hwang, Y.; Lim, M.; Ochir, C.; Lee, K. Daytime profile of residential PM2.5 concentrations in a ger, a traditional residence in Mongolia. Korean J. Public Health 2017, 54, 23-30. [CrossRef]

20. Caldieron, J.; Miller, R. Residential Satisfaction in the Informal Neighborhoods of Ulaanbaatar, Mongolia. Enq. A J. Arch. Res. 2010, 7, 12-18. [CrossRef]

21. Cowlin, S.; Kaufmann, R.B.; Edwards, R.; Smith, K.R. Impact of Improved Stoves on Indoor Air Quality in Ulaanbaatar, Mongolia. Energy Sector Management, 2005. Available online: http:/ /hdl.handle.net/10986/18005 (accessed on 24 April 2021).

22. Ishihara, Y.; Nakao, M.; Yamauchi, K.; Oomori, H.; Ichinnorov, D.; Solongo, B. Effect of Particulate Matter Air Pollution on the Health Status, Respiratory Symptoms, and Lung Function of Mongolian Living in Ger District and Urban Area of Ulaanbaatar. In C55. Cardiopulmonary Effects of air pollution. Am. J. Respir. Crit. Care Med. 2020, 201, A5415.

23. Gheorghe, A.; Ankhbayar, B.; van Nieuwenhuyzen, H.; de Sa, R. Mongolia's Air Pollution Crisis: A Call to Action to Protect Children's Health; National Center for Public Health and UNICEF: Ulaanbaatar, Mongolia, 2018.

24. There Is a High Risk of Infectious Diseases. 2016. Available online: https://ubinfo.mn/ read/7188 (accessed on 5 March 2021). 
25. Kamatas, T.; Reichert, J.A.; Tsevegmid, T.; Kim, Y.; Sedgewick, B. (Eds.) Enhancing Policies and Practices for Ger Area Development in Ulaanbaatar. Conference Version. The International Bank for Reconstruction and Development/The World Bank, 2010. Available online: https:/ / reliefweb.int/sites/reliefweb.int/files/resources/5CB73065BD1F6D8D492576DA001F3 36A-Full_Report.pdf (accessed on 24 April 2021).

26. Guttikunda, S.K.; Lodoysamba, S.; Bulgansaikhan, B.; Dashdondog, B. Particulate pollution in Ulaanbaatar, Mongolia. Air Qual. Atmos. Health 2013, 6, 589-601. [CrossRef]

27. Davy, P.K.; Gunchin, G.; Markwitz, A.; Trompetter, W.J.; Barry, B.J.; Shagjjamba, D.; Lodoysamba, S. Air particulate matter pollution in Ulaanbaatar, Mongolia: Determination of composition, source contributions and source locations. Atmos. Pollut. Res. 2011, 2, 126-137. [CrossRef]

28. Lim, M.; Myagmarchuluun, S.; Ban, H.; Hwang, Y.; Ochir, C.; Lodoisamba, D.; Lee, K. Characteristics of Indoor PM2.5 Concentration in Gers Using Coal Stoves in Ulaanbaatar, Mongolia. Int. J. Environ. Res. Public Health 2018, 15, 2524. [CrossRef] [PubMed] 